\title{
Anthracene Adsorption to Particles and Water-Stable Aggregates of Mangrove Sediment in Jiulong River Estuary, China
}

\author{
Lin Wu ${ }^{1,2}$, Bigui Lin 1,2, Pan Pan 1,2, Beibei Liu,2* \\ ${ }^{1}$ Institute of Environment and Plant Protection, Chinese Academy of Tropical Agricultural Sciences, Haikou, China \\ ${ }^{2}$ Hainan Key Laboratory of Tropical Eco-Circuling Agriculture, Haikou, China \\ Email: *liubeibei1110@126.com
}

How to cite this paper: Wu, L., Lin, B.G., Pan, P. and Liu, B.B. (2021) Anthracene Adsorption to Particles and Water-Stable Aggregates of Mangrove Sediment in Jiulong River Estuary, China. Journal of Environmental Protection, 12, 809-823. https://doi.org/10.4236/jep.2021.1211048

Received: September 23, 2021

Accepted: November 7, 2021

Published: November 10, 2021

Copyright $\odot 2021$ by author(s) and Scientific Research Publishing Inc. This work is licensed under the Creative Commons Attribution International License (CC BY 4.0).

http://creativecommons.org/licenses/by/4.0/

\begin{abstract}
Polycyclic aromatic hydrocarbons (PAHs) pollution in mangroves has drawn much attention, but knowledge of the sorption of PAHs in mangrove sediment is limited. This study investigated the particles and water-stable aggregates (WSA) of mangrove sediment in Jiulong River Estuary, China, and the characteristics of anthracene adsorption to them. The adsorption of anthracene was strongly influenced by the physicochemical and structural properties of sediment particles and WSA. The main sorbents of mangrove sediment were carbonized particles and clays. The porous structure of carbonized particles made it easy to sequestrate sequester the anthracene, and the aging allowed anthracene to move into deeper sites of the carbonized particles. Clays had high anthracene-fixing capacities, and they included organic matters and formed aggregates. The sorption contents coefficient $K_{f}$ of anthracene with WSA of different sizes increased in the order $0.063-0.25 \mathrm{~mm}>0.063 \mathrm{~mm}>$ $0.25-1.0 \mathrm{~mm}>1.0 \mathrm{~mm}$. The order was correlated with which due to the contents and characteristics of organic matters in the aggregates.
\end{abstract}

\section{Keywords}

PAH, Mangrove, Sediment, Particle, Aggregates, Sorption

\section{Introduction}

Polycyclic aromatic hydrocarbons (PAHs) are a group of persistent organic pollutants (POPs) that are ubiquitous in the environment [1] [2]. They have been of particular concern due to their carcinogenicity, mutagenicity and toxicity to bi- 
ota. Mangroves are important inter-tidal estuarine wetlands along the coastlines of tropical and subtropical regions with important environmental protection functions [3] [4]. Human activities in coastal areas extremely increased in recent years and made mangroves suffer great environmental pressures [5] [6]. Over the past few decades, mangrove wetlands have been exposed to multiple poisonous PAHs due to various kinds of human activities [7] [8] [9] [10].

Biodegradation by indigenous degrading microbes and phytoremediation are important processes for PAHs-contaminated mangrove sediments [11] [12] [13] [14]. However, the feasibility and effectiveness of biodegradation are strongly affected by the accessibility and bioavailability of PAHs in sediment [15] [16], which were depended on the particle size distribution and aggregation of soil and sediment [17] [18]. The previous study showed different sized particles perform as different "pools" for PAHs [19] [20]. Thus, the distribution of PAHs in soil particles could affect the bioremediation of these pollutants. Especially after long years of aging, these compounds can move into the inaccessible compartments of soil particles and lead to sequestration, which may reduce extractability and result in low bioavailability [21] [22] [23] [24] [25]. Therefore, it is important to study the sorption of PAHs in mangrove sediment particles and aggregates. Many studies have focused on the distribution of PAHs in different particles of surface soils or sediments, but the results are various because of different sampling sites [19] [26]-[31].

The mangrove sediment has unique properties such as organic-rich matters and fine grains [3]. It was also under a flooded condition which can damage its physical structures through physical dispersion. So that, the particles and water-stable aggregates of mangrove sediment are important for the sorption of PAHs and then influence their degradation. However, the physical composition and structural properties of the mangrove sediments were not reported and its relationship with the sorption of PAHs in sediments was unknown. This study aims at investigating the particles and water-stable aggregates of mangrove sediments and the sorption of a typical $\mathrm{PAH}$, anthracene in these particles and water-stable aggregates.

\section{Materials and Methods}

\subsection{Chemicals}

Standard of anthracene (>99\% purity) was purchased from Sigma Aldrich (USA). The stock solution of anthracene was prepared by dissolving an appropriate amount of regent in anhydrous ethanol, with a final concentration of $100 \mathrm{mg} / \mathrm{L}$. The stock solution was kept in a brown bottle at $4^{\circ} \mathrm{C}$ and wrapped with aluminium foil to avoid any light exposure prior to use. Working solutions of anthracene were prepared by transferring small aliquots of each stock solution into several glass tubes. After allowing evaporation of the solvent by a gentle flow of high-purity nitrogen gas ( $\geq 99.99 \%)$, Mill-Q water was added to the mark of all the colorimetric tubes to obtain a series of the PAHs working solutions for sorp- 
tion experiment. The trichloromethane and methanol used for PAH analysis were HPLC-grade solvents purchased from Tedia (USA). The calcium chloride $\left(\mathrm{CaCl}_{2}\right)$ used for adsorption experiment was analysis grade purchased Sigma Aldrich (USA).

\subsection{Sediment}

The surface $(0-10 \mathrm{~cm})$ sediment sample was collected from the mangrove wetland $\left(24^{\circ} 29^{\prime} \mathrm{N}, 117^{\circ} 55^{\prime} \mathrm{E}\right)$ in Jiulong River Estuary, which is one of the largest river/estuary systems in south China and is the major drinking water source for Xiamen and the main freshwater source for its sea area [11]. The wet sediment was brought back to the laboratory and used for separating particles and water-stable aggregates immediately. The other portion of sampled sediment was air-dried and passed through a $2 \mathrm{~mm}$ sieve and the dry sieved sediment was used for the anthracene sorption experiment.

Selected properties of the mangrove sediment were determined [32] and as follows: $\mathrm{pH}$ (in $\mathrm{H}_{2} \mathrm{O}$ ) 6.66, organic matter $28.4 \mathrm{~g} / \mathrm{kg}$, total $\mathrm{N} 1.13 \mathrm{~g} / \mathrm{kg}$, total $\mathrm{P}$ $0.85 \mathrm{~g} / \mathrm{kg}$, and total K $19.2 \mathrm{~g} / \mathrm{kg}$. The background concentrations of the studied PAHs in the sediment proved to be $<2 \%$ of the lab-added concentrations.

\subsection{Sediment Particle Separation}

The sediment was physically separated by a size and density separation method as described by Ghosh (2000) [26]. Wet sieving was first performed to separate the sediment into four size fractions $(>1.0,1.0-0.25,0.25-0.063$, and $<0.063$ $\mathrm{mm})$. The larger size fractions $(>0.063 \mathrm{~mm})$ comprised primarily of sand grains, coal-derived particles, and woody material. It was possible to wash off the lighter fractions (coal and wood) from the heavier sand by swirling with water in a beaker and draining off the entrained lighter particles. Materials in the fine fraction $(<0.063 \mathrm{~mm})$ were density separated using a cesium chloride solution having a specific gravity of 1.8 . Five grams of wet sediment and $40 \mathrm{~mL}$ of cesium chloride solution were centrifuged at $200 \mathrm{rpm}$ for $10 \mathrm{~min}$ in $50 \mathrm{~mL}$ glass centrifuge tubes. The fine coal-derived and wood particles floated, were decanted, and were collected on filter paper and rinsed with water several times. The heavy clay and silt fractions were similarly washed several times to remove cesium chloride. Each of these sizes and density separated fractions was then weighted and investigated for particle structures by a scanning electron microscope (SEM, HITACHI S-4800 FE-SEM).

\subsection{Sediment Water-Stable Aggregates (WSA) Separation}

The WSA of the sediment was analyzed by using a slight modification of the wet-sieving technique described by Elliott (1986) [33]. Briefly, the moist sediment samples were wet sieved manually through a series of three sieves to obtain four size fractions: $(>1.0,1.0-0.25,0.25-0.063$, and $<0.063 \mathrm{~mm})$. The WSA in each size fraction was collected, dried and weighed. 


\subsection{PAH Sorption in Sediment Particles}

The PAH contaminated sediments were prepared according to the method described by Hatzinger and Alexander (1995) [34]. The dry sieved sediments were sterilized by an autoclave at $103.4 \mathrm{kPa}$ and $121.3^{\circ} \mathrm{C}$ for $2 \mathrm{~h}$ to prevent any microbial activity during the sorption experiment. $500 \mathrm{ng} / \mathrm{mL}$ anthracene was prepared by taking $250 \mu \mathrm{L}$ of anthracene stock solutions to a $50 \mathrm{~mL}$ brown volumetric flask; methanol was added to the mark after allowing evaporation of the solvent by a gentle flow of high-purity nitrogen gas ( $\geq 99.99 \%)$. Then $20.00 \mathrm{~g}$ portions of sterilized sediments were added to sterilized $50 \mathrm{~mL}$ screw-cap test tubes. To each tube was added $2 \mathrm{~mL}$ anthracene solution. The liquid was added dropwise to bring the anthracene concentration to $50 \mathrm{ng} / \mathrm{g}$ dry weight $(\mathrm{dw})$ sediment.

Several tubes were placed in a hood for $1 \mathrm{~h}$, and the samples were shaken to allow the methanol to evaporate and to ensure thorough mixing of PAH with the sediments. Deionized water was then added to bring the moisture level of sediments to $50 \%(\mathrm{~W} / \mathrm{W})$; and the other tubes with $\mathrm{PAH}$ contaminated sediments incubated in the dark at $20^{\circ} \mathrm{C} \pm 11^{\circ} \mathrm{C}$ for aging $100 \mathrm{~d}$ [35] [36].

The fresh and aged PAH contaminated sediments were size and density separated by the method described above, each of these sizes and density separated fractions were then analyzed for PAH concentration by GC-MS.

\subsection{PAHs Sorption in WSA}

The WSA of sediment with four size fractions (>1.0, $1.0-0.25,0.25-0.063$, and $<0.063 \mathrm{~mm}$ ) were obtained by wet sieving and each aggregate fraction was air-dried and sterilized at $103.4 \mathrm{kPa}, 121.3^{\circ} \mathrm{C}$ for $2 \mathrm{~h}$ to remove the effect of microorganisms. The sorption isotherm experiments of anthracene on each size of WSA were conducted. According to the preliminary experiment, the appropriate ratio of water to soil was 25 to 1 ; the initial concentrations of anthracene in 0.01 $\mathrm{mol} / \mathrm{L} \mathrm{CaCl}_{2}$ solutions were between $5.0 \mu \mathrm{g} / \mathrm{L}$ to $100.0 \mu \mathrm{g} / \mathrm{L}$, and the equilibration time was $48 \mathrm{~h} .100 \mu \mathrm{g} / \mathrm{mL} \mathrm{HgCl}_{2}$ was contained in each colorimetric tube to inhibit microbial activity during the experimental process. Transfer $0.20 \mathrm{~g}$ dried sediment aggregate sample into a series of $10 \mathrm{~mL}$ glass tubes with caps, and then each of them was spiked with $5 \mathrm{~mL}$ individual anthracene solution. The tube caps were sealed tightly with Parafilm to prevent the loss of PAH from solvent evaporation. The sealed tubes were rotated in a rocking bed in dark with a speed of $45 \mathrm{rpm}$ for $48 \mathrm{~h}$ at room temperature. After $48 \mathrm{~h}$, samples were centrifuged at $2500 \mathrm{rpm}$ for $25 \mathrm{~min}$. The supernatants were transferred to the amber glass vials, and the concentrations of anthracene in supernatants were determined by the GC-MS.

All of the sorption isotherm experimental data were fitted to two sorption models: the Linear model and Freundlich model, which were usually used to describe sorption behaviour of organic pollutants in soil or sediment. Linear model is described as the equation $q_{e}=K_{d} C_{e}$ and the Freundlich model is described as the equation $q_{e}=K_{f} C_{e}^{n}$, where $q_{e}(\mu \mathrm{g} / \mathrm{kg})$ is the amount of the anthracene ad- 
sorbed by sediment, $C_{e}(\mu \mathrm{g} / \mathrm{L})$ is the anthracene concentration remaining in equilibrium in the solution, $K_{d}(\mathrm{~L} / \mathrm{kg})$ is the partition coefficient of the Linear model, $K_{f}(\mu \mathrm{g} / \mathrm{kg}) /(\mu \mathrm{g} / \mathrm{L})^{\mathrm{n}}$ and $n$ are Freundlich constants $\left(K_{f}\right.$ related to sorption capacity and $n$ related to the sorption intensity). $q_{e}$ is calculated by the equation $q_{e}=\left(C_{0}-C_{e}\right) \times V / m$, where $C_{0}$ is the initial concentration of anthracene in solution, $V$ is the volume of solution and $m$ was the mass of sediment [37].

\subsection{PAH Analysis}

PAH in sediments were extracted by a method reported by Tam et al. (2001) [38]. Ten grams of freeze-dried sediment sample was ultrasonicated with $50 \mathrm{~mL}$ mixture of trichloromethane and methanol $(2: 1 \mathrm{v} / \mathrm{v})$ in an ultrasonic bath for 15 $\min$. The second extraction was conducted with $50 \mathrm{~mL}$ mixture of trichloromethane and methanol $(1: 2 \mathrm{v} / \mathrm{v})$. The two extracts were combined and $45 \mathrm{~mL}$ Milli-Q water was added to discard the methanol phase. The extract was concentrated to around $1 \mathrm{~mL}$ by rotary evaporation at $23^{\circ} \mathrm{C}$. The $\mathrm{PAH}$ in supernatants was also ultrasonicated with trichloromethane $(1: 1 \mathrm{v} / \mathrm{v})$ twice and the two extracts were mixed.

The obtained extracts were dehydrated with anhydrous sodium sulfate, then reduced by a rotary evaporator to about $1 \mathrm{~mL}$ and cleaned up with silica gel columns [39] and then determined by a GC-MS (Thermo TSQ Quanum GC, USA). The determination conditions were as follows, the column was TR-5MS $(30 \mathrm{~m} \times 0.25 \mathrm{~mm} \times 0.25 \mu \mathrm{m})$, the injector temperature was $260^{\circ} \mathrm{C}$, the oven temperature was to increase from $60^{\circ} \mathrm{C}$ to $200^{\circ} \mathrm{C}$ at $25^{\circ} \mathrm{C} / \mathrm{min}$ and then to $310^{\circ} \mathrm{C}$ at $8^{\circ} \mathrm{C} / \mathrm{min}$, under the selected ions monitoring mode, the mass to charge ratio was set at $128 \mathrm{~m} / \mathrm{z}$ in the first eight minutes, at $178 \mathrm{~m} / \mathrm{z}$ from the eighth minute to the fourteenth minute, and $252 \mathrm{~m} / \mathrm{z}$ from the fourteenth minute to the twenty-third minute, the solvent delay was set at four minutes, helium was used as the carrier gas, and the flowing rate of carrier gas was $1 \mathrm{~mL} / \mathrm{min}$. The recoveries of PAHs in water and soil were $97 \%-105 \%$ and $87.3 \%-91.66 \%$ respectively.

\subsection{Statistical Analyses}

All of these experiments were performed in triplicates and the results presented were average values of the three replicates. Data were analyzed statistically using analysis of variance (ANOVA) and Duncan's multiple range tests were employed to determine the significance of the differences between the parameters. The statistical package used was the SPSS statistical software package (Version 11.0 ) and the confidence limit was $95 \%$.

\section{Results and Discussion}

\subsection{Sediment Particle Characterization}

Table 1 presents the proportions of each size and density separated fraction in the sediment. Heavy fractions in the sediment constituted about $99 \%$ of the 
Table 1. Type and mass percentage of particles in different sizes and density fractions of sediment.

\begin{tabular}{ccccc}
\hline & \multicolumn{2}{c}{ Heavy fraction } & Light fraction \\
\cline { 2 - 5 }$\left(\begin{array}{c}\text { Size } \\
(\mathrm{mm})\end{array}\right.$ & Particle type & $\begin{array}{c}\text { \% of whole } \\
\text { sediment mass }\end{array}$ & Particle type & $\begin{array}{c}\text { \% of whole } \\
\text { sediment } \\
\text { mass }\end{array}$ \\
\hline$>1.0$ & Plant residue & 0.118 & sand & 0.310 \\
$0.25-1.0$ & Plant debris & 0.165 & fine sand & 1.32 \\
$0.063-0.25$ & Coal, coke & 0.735 & dilt & 5.92 \\
$<0.063$ & - & - & Silt, clay & 91.8 \\
\hline
\end{tabular}

sediment mass, while light fractions constituted the remaining $1 \%$ of the sediment weight. The most abundant component in the mangrove sediment is $<0.063 \mathrm{~mm}$ heavy fraction which occupied $92 \%$ of the whole sediment weight. The content of the light fraction with the size of $0.063-0.25 \mathrm{~mm}$ was higher than the other size light fractions.

Particle structures in each size and density separated fraction were then investigated using SEM, and the results are shown in Figure 1 and Figure 2. Figure 1 shows that the particles in the light fractions of the mangrove sediment are mainly structural organic materials, including plant residues and fragments and carbonaceous particles (such as coal dust, coke, and so on). Plant residues and fragments is the plant residue suffering natural wear and decay which retained some plant tissue structure (Figure 1(a) and Figure 1(b)); Carbonaceous particles are the product of coal in the use of leakage and transportation or by the product of high-temperature combustion which is irregular globular and has obvious porosity structure, and with the size of $0.063-0.25 \mathrm{~mm}$ (Figure $1(\mathrm{c}$ ) and Figure 1(d)).

Figure 2 shows that the particles in the heavy fractions of the mangrove sediment are mainly sand, silt, clay and other inorganic minerals. The sand particles are single grains, and with larger grain size which is more distributed in the fractions of $>0.25 \mathrm{~mm}$ size (Figure 2(a)); the clay particles are composite grain and have laminated structure; the particle size is small and is more distributed in the fraction of $<0.063 \mathrm{~mm}$ (Figure 2(b)).

In addition, sediment aggregates particles were observed in $>1.0 \mathrm{~mm}$ heavy fractions (Figure 2(c)) which indicates a stable structure contrary to the unconsolidated sediment. According to the development model of aggregates proposed by Tisdall and Oades (1982) [40], the formation of aggregates maybe because the mangrove sediment had a high content of organic matters and clays which offer a wealth of organic and inorganic colloid to form organic substance-inorganic mineral aggregates. 


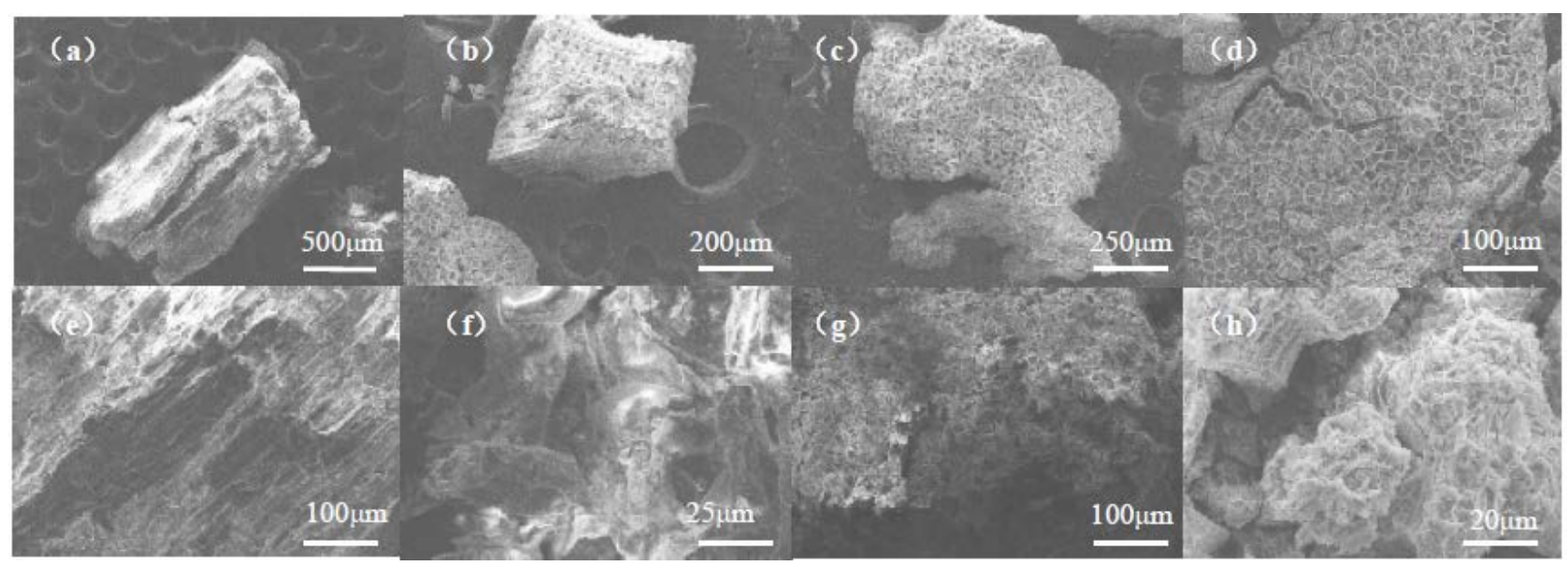

Figure 1. SEM images of typical particles in light fractions of sediment, (a), (b): woody debris, (c), (d): coal-derived particles, (e) to (h): the microstructures of (a) to(d).

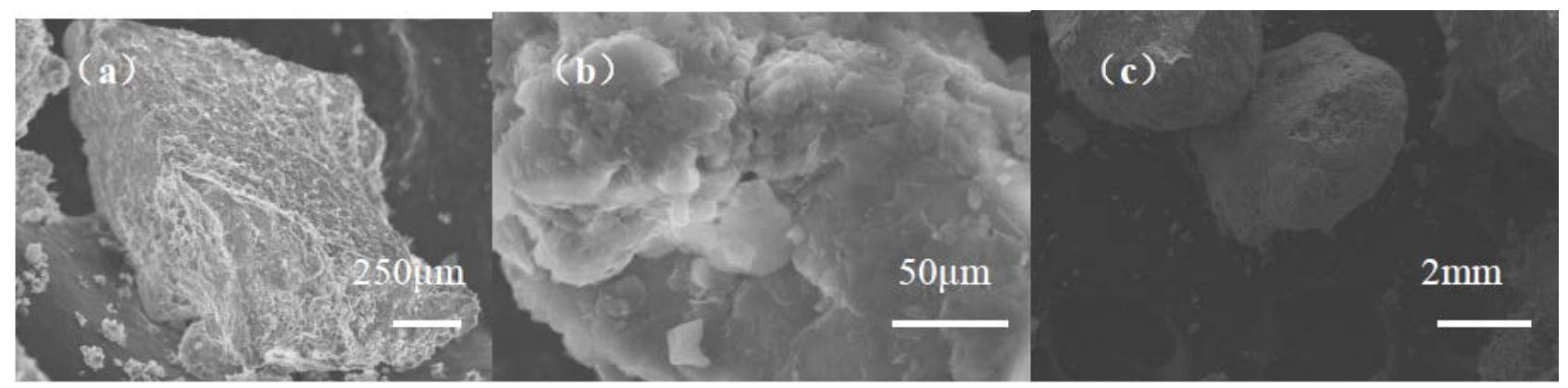

Figure 2. SEM images of typical particles in heavy fractions of sediment, (a) sand; (b) clay, (c) macroaggregate.

\subsection{The Distribution of PAH in Sediment Particles}

The concentrations of unaged and aged anthracene in each size and density separated fraction were analyzed and the results are shown in Table 2. The heavy fractions sorbed $83 \%$ of anthracene and the light fractions sorbed $17 \%$ of anthracene. But from the weight of each component, the amounts of sorbed anthracene per light fraction unit were much higher than that of heavy fraction. After aging, the proportion of sorbed anthracene in $<0.063 \mathrm{~mm}$ fraction decreased, but the proportion of sorbed anthracene in $>1.0 \mathrm{~mm}$ heavy fraction obviously increased. The proportion of sorbed anthracene in each light fraction all increased.

Plant residues and detritus had large sizes and visible porous structures, as shown in Figure 1(a) and Figure 1(b). Coal-derived particles had smaller sizes (mostly existed in the 0.063 - $0.25 \mathrm{~mm}$ fractions), and deeper pores (Figure 1 (g), and Figure $1(\mathrm{~h})$ ). The large surface area and porous structures of these particles were easy to sequestrate $\mathrm{PAH}$ molecules, and this is why light fractions absorbed more PAHs than heavy fractions. The previous studies also found coal and coal-derived particles were dominant geosorbents for PAHs in a river floodplain soil [31] [41] [42] [43]. And with the time increased, PAH molecules may move into deeper positions of the particles and difficult to be extracted, thus, the 
Table 2. Distribution proportions and weight values ${ }^{\star}$ of unaged and aged anthracene in different size and density separated fractions.

\begin{tabular}{ccccc}
\hline \multirow{2}{*}{$\begin{array}{c}\text { Size and density sepa- } \\
\text { rated fractions }\end{array}$} & $\begin{array}{c}\text { Unaged anthracene } \\
\text { \% of the total } \\
\text { amount }\end{array}$ & Weight & $\begin{array}{c}\text { \% of the total } \\
\text { amount }\end{array}$ & Weight \\
\hline Heavy $<0.063 \mathrm{~mm}$ & 78.56 & 0.86 & 72.80 & 0.79 \\
Heavy 0.063 - 0.25 mm & 0.96 & 0.16 & 0.59 & 0.10 \\
Heavy 0.25 - $1.0 \mathrm{~mm}$ & 0.38 & 0.29 & 0.30 & 0.22 \\
Heavy > $1.0 \mathrm{~mm}$ & 3.25 & 10.50 & 4.97 & 16.04 \\
Sum of heavy fractions & 83.16 & 11.80 & 78.66 & 17.15 \\
Light 0.063 - 0.25 mm & 7.59 & 10.33 & 9.07 & 12.35 \\
Light 0.25 - $1.0 \mathrm{~mm}$ & 4.29 & 26.00 & 5.06 & 30.65 \\
Light $>1.0 \mathrm{~mm}$ & 4.96 & 42.08 & 7.21 & 61.13 \\
Sum of light fractions & 16.84 & 78.40 & 21.34 & 104.12 \\
\hline
\end{tabular}

${ }^{\star}$ Weight $=$ Proportions of anthracene distributed to each fraction (\%)/Proportions of each fraction in sediment mass (\%).

contents of the $\mathrm{PAH}$ in this fraction increased after aging.

The main particles in $0.063-0.25 \mathrm{~mm}$ and $0.25-1.0 \mathrm{~mm}$ heavy fractions, sand and silt, had low sorption capacity of PAHs. That is why the contents of PAHs in these fractions were smaller than others. Clays that existed in $<0.063 \mathrm{~mm}$ fraction have stratified structures and large surface areas, thus easy to absorb PAHs. Moreover, the clays made up a high proportion of the mangrove sediment and thus they absorbed most of PAHs. After aging, the contents of the PAHs decreased in $<0.063 \mathrm{~mm}$ fraction, but increased in $>1.0 \mathrm{~mm}$, heavy fraction. It was probably because aging caused the PAHs to penetrate deeper into sediment aggregates, which were observed in $>1.0 \mathrm{~mm}$, heavy fraction.

\subsection{The Physical Structure and Chemical Properties of Sediment Aggregates}

The above experiment results showed that sediment aggregates affected the PAHs sorption obviously. So we did further study focused on the characters of sediment aggregates and PAHs sorption in which. The microstructure of WSA with different sizes of the sediment was investigated by using SEM, as shown in Figure 3. Figure 3 shows that the inorganic mineral particles in the sediment bond together or adhere to the skeleton particles and shape microorganisms (Figure 3(a) and Figure 3(b)); then the microaggregate bond together and form macroaggregate which is arranged by single grain and have pore between crumb (Figure 3(c) and Figure 3(d)). Tisdall and Oades (1982) [40] proposed an aggregate development model, which described that the primary mineral particles and bacteria, fungi and plants debris first cemented to microaggregates, then these free microaggregate was bound together by instantaneous degeneration 


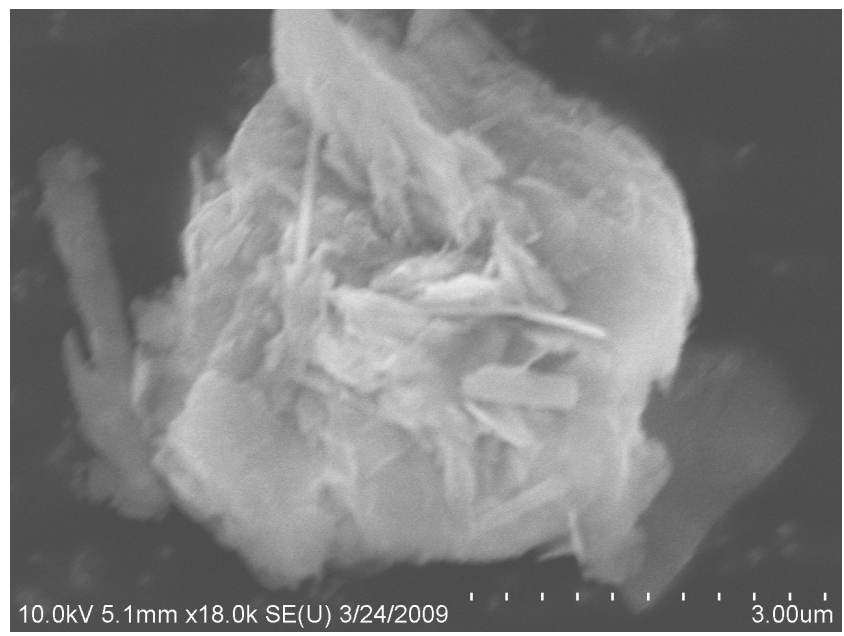

(a)

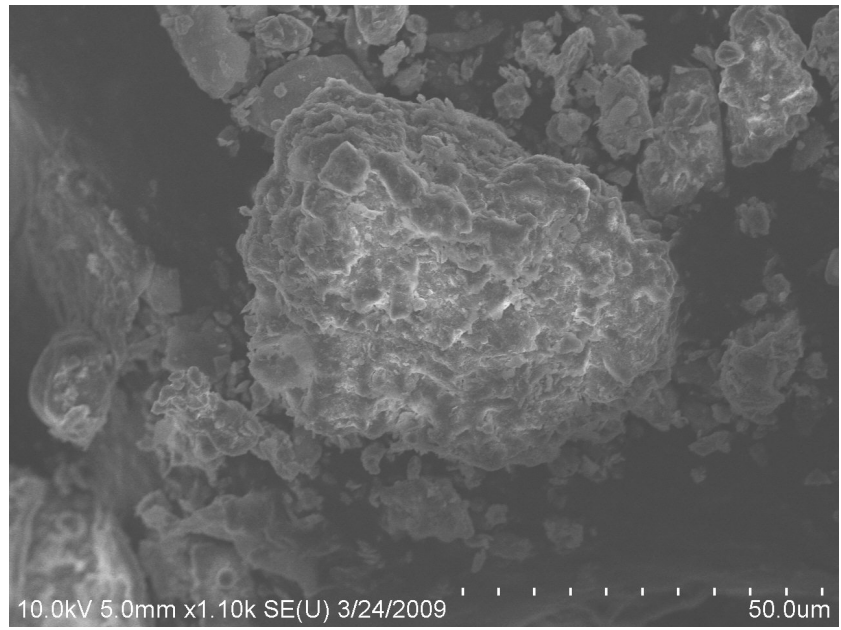

(c)

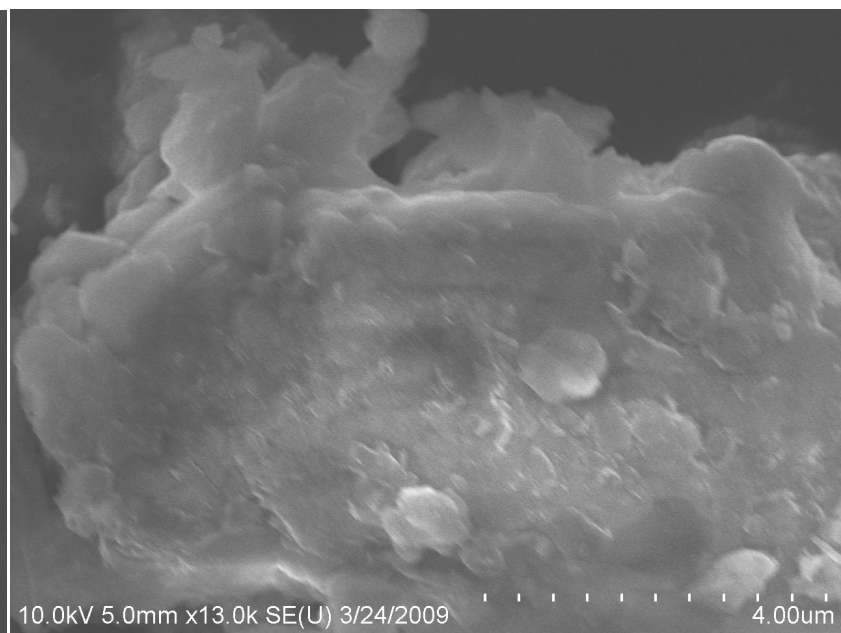

(b)

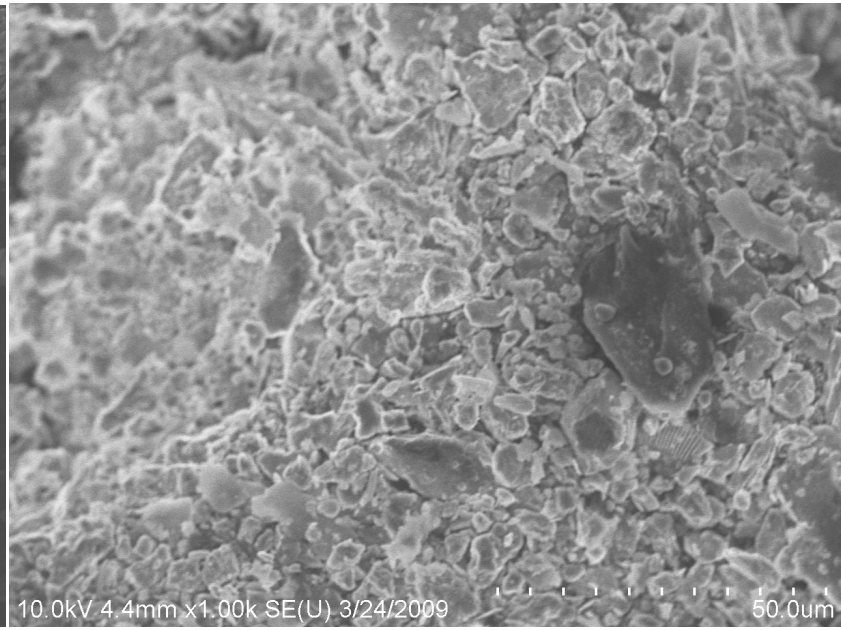

(d)

Figure 3. SEM images of sediment aggregates in sediment, (a) $<0.063 \mathrm{~mm}$ microaggregate, (b) $0.063-0.25 \mathrm{~mm}$ microaggregate, (c) $0.25-1.0 \mathrm{~mm}$ macroaggregate, (d) $>1.0 \mathrm{~mm}$ macroaggregate.

cementing agent (microorganisms and plant polysaccharides) and temporary cementing agent (root and fungal mycelium) and formed macroaggregate. The result was consistent with our experimental observation results.

The chemical properties of sediment aggregate are shown in Table 3. Table 3 shows that TOC content of aggregate with different size were decreased in the order $0.063-0.25 \mathrm{~mm}>0.25-1.0 \mathrm{~mm}>1.0 \mathrm{~mm}>0.063 \mathrm{~mm}$. This phenomenon can be explained by the particle components of the sediment as discussed above. The plant debris and carbonaceous particles mainly distribute in the fraction of $0.25-1.0 \mathrm{~mm}$ and $0.063-0.25 \mathrm{~mm}$ (see Table 1 ), which made the higher TOC content of the aggregates with these two sizes. The value of $\mathrm{C} / \mathrm{N}$ of the aggregates is in accordance with the TOC content. The BC content of aggregate with different size decreased in the order $0.063-0.25 \mathrm{~mm}>0.063 \mathrm{~mm}>0.25-1.0$ $\mathrm{mm}>1.0 \mathrm{~mm}$, which are different with the order of TOC content. It indicated that the organic components of the aggregates with different size are different; 
and the aggregates with the size of $0.063-0.25 \mathrm{~mm}$ and $<0.063 \mathrm{~mm}$ had more compactness organic matter. The specific surface area of aggregate increased with the particle size.

\subsection{PAH Sorption in Sediment Aggregates}

The sorption isotherm data for anthracene in different size aggregates are shown in Figure 4. The fitting parameters from the Linear model and Freundlich model are presented in Table 4. From Table 4, it can be seen that both Linear and Freundlich models fit the experimental data very well. For most of the four aggregate sizes, the Freundlich model had higher $\mathrm{R}^{2}$ values, which indicated that Freundlich model fit the data better than Linear model. Based on Freundlich model parameters, the sorption capacities of these different aggregates were observed to follow the order: $0.063-0.25 \mathrm{~mm}$ aggregate $>0.25-1.0 \mathrm{~mm}$ aggregate $>0.063 \mathrm{~mm}$ aggregate $>1.0 \mathrm{~mm}$ aggregate. From the TOC and C/N values of different size aggregates, as shown in Table 4, it can be seen that, the higher sorption capacity of $0.063-0.25 \mathrm{~mm}$ aggregate can be explained by its higher TOC and $\mathrm{C} / \mathrm{N}$.

From Table 4, it can also be seen that the $\mathrm{n}$ values of Freundlich model for most types of aggregates were less than 1, which indicated that the sorption of PAHs on these aggregates was nonlinear. The $\mathrm{n}$ value of $>1.0 \mathrm{~mm}$ aggregates was smaller than that of others, which indicated that the non-Linearity of the sorption of PAH in $>1.0 \mathrm{~mm}$ aggregates was higher than that of others. That may be

Table 3. Selected characteristics of sediment aggregates with different sizes.

\begin{tabular}{cccccc}
\hline Size $(\mathrm{mm})$ & $\begin{array}{c}\text { TOC } \\
(\mathrm{g} / \mathrm{kg})\end{array}$ & $\begin{array}{c}\mathrm{N} \\
(\mathrm{g} / \mathrm{kg})\end{array}$ & $\mathrm{C} / \mathrm{N}$ & $\begin{array}{c}\mathrm{BC} \\
(\mathrm{g} / \mathrm{kg})\end{array}$ & $\begin{array}{c}\text { Specific } \\
\text { surface } \\
\text { area }\left(\mathrm{m}^{2} / \mathrm{g}\right)\end{array}$ \\
\hline$>1.0$ & $14.36^{\mathrm{c}}$ & $1.04^{\mathrm{c}}$ & 13.76 & $1.23^{\mathrm{d}}$ & $26.35^{\mathrm{d}}$ \\
$0.25-1.0$ & $16.76^{\mathrm{b}}$ & $1.08^{\mathrm{b}}$ & 15.48 & $1.36^{\mathrm{c}}$ & $27.37^{\mathrm{c}}$ \\
$0.063-0.25$ & $42.07^{\mathrm{a}}$ & $2.44^{\mathrm{a}}$ & 17.23 & $3.51^{\mathrm{a}}$ & $35.51^{\mathrm{b}}$ \\
$<0.063$ & $11.18^{\mathrm{d}}$ & $0.82^{\mathrm{d}}$ & 13.67 & $1.95^{\mathrm{b}}$ & $48.95^{\mathrm{a}}$
\end{tabular}

The different superscript lower-case letters in each column indicate significant differences.

Table 4. The sorption parameters of anthracene in sediment aggregates with different sizes.

\begin{tabular}{cccccc}
\hline \multirow{2}{*}{ Aggergate size } & \multicolumn{2}{c}{ Linear model } & \multicolumn{3}{c}{ Freundlich model } \\
\cline { 2 - 6 } & $K_{d}(\mathrm{~L} / \mathrm{kg})$ & $\mathrm{R}^{2}$ & $K_{f}(\mu \mathrm{g} / \mathrm{kg}) /(\mu \mathrm{g} / \mathrm{L})^{\mathrm{n}}$ & $\mathrm{n}$ & $\mathrm{R}^{2}$ \\
\hline$>1.0 \mathrm{~mm}$ & $231.73 \pm 25.7$ & 0.9821 & $470.92 \pm 72.9$ & $0.71 \pm 0.07$ & 0.9844 \\
$0.25-1.0 \mathrm{~mm}$ & $361.43 \pm 25.1$ & 0.9920 & $536.93 \pm 37.8$ & $0.80 \pm 0.04$ & 0.9963 \\
$0.063-0.25 \mathrm{~mm}$ & $690.08 \pm 65.5$ & 0.9862 & $863.72 \pm 78.2$ & $0.83 \pm 0.08$ & 0.9854 \\
$<0.063 \mathrm{~mm}$ & $315.53 \pm 18.5$ & 0.9943 & $529.15 \pm 17.0$ & $0.75 \pm 0.01$ & 0.9993 \\
\hline
\end{tabular}




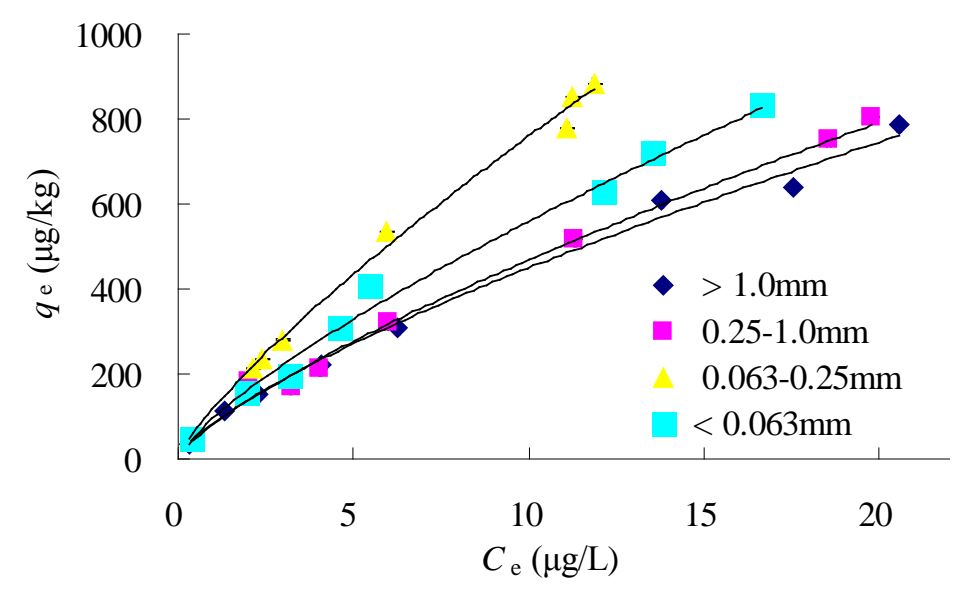

Figure 4. Sorption isotherms of anthracene in aggregates with different sizes.

caused by the heterogenic surfaces of the bigger aggregates, which were the combinations of organic matters and minerals.

\section{Conclusion}

The results showed that the sorption of anthracene was strongly influenced by the physicochemical and structural properties of sediment particles and WSA. The main sorbents of mangrove sediment were carbonized particles and clays. The porous structure of carbonized particles made it easy to sequestrate the $\mathrm{PAH}$, and the aging made the PAH come into deeper sites of the carbonized particles; clays had good PAH-fixing capacities and they always combined by organic matters and formed aggregates; the sorption contents $K_{f}$ of the PAH in WSA with different size increased in the order $0.063-0.25 \mathrm{~mm}>0.063 \mathrm{~mm}>$ $0.25-1.0 \mathrm{~mm}>1.0 \mathrm{~mm}$, and the differences were due to the contents and characters of organic matters in aggregates.

\section{Acknowledgements}

This work was supported by the Hainan Provincial Key Research and Development Projects (ZDYF2021SHFZ066, ZDYF2019221), and the National Natural Science Foundation of China (41301555).

\section{Conflicts of Interest}

The authors declare no conflicts of interest regarding the publication of this paper.

\section{References}

[1] Shen, H.Z., Huang, Y., Wang, R., Zhu, D., Li, W., Shen, G.F., Wang, B., Zhang, Y.Y., Chen, Y.C., Lu, Y., Chen, H., Li, T.C., Sun, K., Li, B.G., Liu,W.X., Liu, J.F. and Tao, S. (2013) Global Atmospheric Emission of Polycyclic Aromatic Hydrocarbons from 1960 to 2008 and Future Prediction. Environmental Science \& Technology, 47, 6415-6424. https://doi.org/10.1021/es400857z 
[2] Bayen, S. (2012) Occurrence, Bioavailability and Toxic Effects of Trace Metals and Organic Contaminants in Mangrove Ecosystems: A Review. Environment International, 48, 84-101. https://doi.org/10.1016/j.envint.2012.07.008

[3] Zhang, Z.W., Xu, X.R., Sun, Y.X., Yu, S., Chen, Y.S. and Peng, J.X. (2014) Heavy metal and Organic Contaminants in Mangrove Ecosystems of China: A Review. Environmental Science and Pollution Research, 21, 11938-11950. https://doi.org/10.1007/s11356-014-3100-8

[4] Wang, Y.S. and Gu, J.D. (2021) Ecological Responses, Adaptation and Mechanisms of Mangrove Wetland Ecosystem to Global Climate Change and Anthropogenic Activities. International Biodeterioration \& Biodegradation, 162, Article ID: 105248. https://doi.org/10.1016/j.ibiod.2021.105248

[5] Raza, M., Zakaria, M.P., Hashim, N.R., Yim, U.H., Kannan, N. and Ha, S.Y. (2013) Composition and Source Identification of Polycyclic Aromatic Hydrocarbons in Mangrove Sediments of Peninsular Malaysia: Indication of Anthropogenic Input. Environmental Earth Sciences, 70, 2425-2436. https://doi.org/10.1007/s12665-013-2279-1

[6] Neba, G., Anyinkeng, N., Mumbang, C. and Fonge, A. (2021) Benthic Algal Community in Relationship to Perturbation in the Tiko Mangrove Estuary Cameroon. Open Journal of Ecology, 11, 540-564. https://doi.org/10.4236/oje.2021.117035

[7] Qiu, Y.W., Qiu, H.L., Li, J. and Zhang, G. (2018) Bioaccumulation and Cycling of Polycyclic Aromatic Hydrocarbons (PAHs) in Typical Mangrove Wetlands of Hainan Island, South China. Archives of Environmental Contamination and Toxicology, 75, 464-475. https://doi.org/10.1007/s00244-018-0548-4

[8] Balu, S., Bhunia, S., Gachhui, R. and Mukherjee, J. (2020) Assessment of Polycyclic Aromatic Hydrocarbon Contamination in the Sundarbans, the World's Largest Tidal Mangrove Forest and Indigenous Microbial Mixed Biofilm-Based Removal of the Contaminants. Environmental Pollution, 266, Article ID: 115270.

https://doi.org/10.1016/j.envpol.2020.115270

[9] Verâne, J., dos Santos, N.C.P., da Silva, V.L., de Almeida, M., de Oliveira, O.M.C. and Moreira, Í.T.A. (2020) Phytoremediation of Polycyclic Aromatic Hydrocarbons (PAHs) in Mangrove Sediments Using Rhizophora mangle. Marine Pollution Bulletin, 160, Article ID: 111687. https://doi.org/10.1016/j.marpolbul.2020.111687

[10] Garcia, M.R. and Martins, C.C. (2021) A Systematic Evaluation of Polycyclic Aromatic Hydrocarbons in South Atlantic Subtropical Mangrove Wetlands under a Coastal Zone Development Scenario. Journal of Environmental Management, 277, Article ID: 111421. https://doi.org/10.1016/j.jenvman.2020.111421

[11] Tian, Y., Liu, H.J., Zheng, T.L., Kwon, K.K., Kim, S.J. and Yan, C.L. (2008) PAHs Contamination and Bacterial Communities in Mangrove Surface Sediments of the Jiulong River Estuary, China. Marine Pollution Bulletin, 57, 707-715.

https://doi.org/10.1016/j.marpolbul.2008.03.011

[12] Wongwongsee, W., Chareanpat, P. and Pinyakong, O. (2013) Abilities and Genes for PAH Biodegradation of Bacteria Isolated from Mangrove Sediments from the Central of Thailand. Marine Pollution Bulletin, 74, 95-104. https://doi.org/10.1016/j.marpolbul.2013.07.025

[13] Moghadam, M.S., Ebrahimipour, G., Abtahi, B., Ghassempour, A. and Hashtroudi, M.S. (2014) Biodegradation of Polycyclic Aromatic Hydrocarbons by a Bacterial Consortium Enriched from Mangrove Sediments. Journal of Environmental Health Science and Engineering, 12, Article No. 114.

https://doi.org/10.1186/s40201-014-0114-6 
[14] Bacosa, H.P. and Inoue, C. (2015) Polycyclic Aromatic Hydrocarbons (PAHs) Biodegradation Potential and Diversity of Microbial Consortia Enriched from Tsunami Sediments in Miyagi, Japan. Journal of Hazardous Materials, 283, 689-697. https://doi.org/10.1016/j.jhazmat.2014.09.068

[15] Chen, J.L., Wong, Y.S. and Tam, N.F.Y. (2009) Static and Dynamic Sorption of Phenanthrene in Mangrove Sediment Slurry. Journal of Hazardous Materials, 168, 1422-1429. https://doi.org/10.1016/j.jhazmat.2009.03.043

[16] Chen, J.L., Wong, M.H., Wong, Y.S. and Tam, N.F.Y. (2011) Modeling Sorption and Biodegradation of Phenanthrene in Mangrove Sediment Slurry. Journal of Hazardous Materials, 190, 409-415. https://doi.org/10.1016/j.jhazmat.2011.03.060

[17] Weissenfels, W.D., Klewer, H.J. and Langhoff, J. (1992) Adsorption of Polycyclic Aromatic Hydrocarbons (PAHs) by Soil Particles: Influence on Biodegradability and Biotoxicity. Applied Microbiology and Biotechnology, 36, 689-696. https://doi.org/10.1007/BF00183251

[18] Lu, Z., Zeng F.G., Xue, N.D. and Li, F.S. (2012) Occurrence and Distribution of Polycyclic Aromatic Hydrocarbons in Organo-Mineral Particles of Alluvial Sandy Soil Profiles at a Petroleum-Contaminated Site. Science of the Total Environment, 433, 50-57. https://doi.org/10.1016/j.scitotenv.2012.06.036

[19] Müller, S., Wilcke, W., Kanchanakool, N. and Zech, W. (2000) Polycyclic Aromatic Hydrocarbons (PAHs) and Polychlorinated Biphenyls (PCBs) in Particle-Size Separates of Urban Soils in Bangkok, Thailand. Soil Science, 165, 412-419. https://doi.org/10.1097/00010694-200005000-00005

[20] Krauss, M. and Wilcke, W. (2002) Sorption Strength of Persistent Organic Pollutants in Particle-Size Fractions of Urban Soils. Soil Science Society of America Journal, 66, 430-437. https://doi.org/10.2136/sssaj2002.4300

[21] Reid, B.J., Jones, K.C. and Semple, K.T. (2000) Bioavailability of Persistent Organic Pollutants in Soils and Sediments-A Perspective on Mechanisms, Consequences and Assessment. Environmental Pollution, 108, 103-112. https://doi.org/10.1016/S0269-7491(99)00206-7

[22] Amellal, N., Portal, J.M. and Berthelin, J. (2001) Effect of Soil Structure on the Bioavailability of Polycyclic Aromatic Hydrocarbons within Aggregates of a Contaminated Soil. Applied Geochemistry, 16, 1611-1619. https://doi.org/10.1016/S0883-2927(01)00034-8

[23] Amellal, N., Portal, J.M., Vogel, T. and Berthelin, J. (2001) Distribution and Location of Polycyclic Aromatic Hydrocarbons (PAHs) and PAH-Degrading Bacteria within Polluted Soil Aggregates. Biodegradation, 12, 49-57.

https://doi.org/10.1023/A:1011909107858

[24] Huang, Q., Li, F.S. and Hong, C. (2007) Aging Behaviour of Polycyclic Aromatic Hydrocarbons in Organo-Mineral Aggregates from Black Soil. Transactions of Beijing Institute of Technology, 27, 937-940.

[25] Haritash, A.K. and Kaushik, C.P. (2009) Biodegradation Aspects of Polycyclic Aromatic Hydrocarbons (PAHs): A Review. Journal of Hazardous Materials, 169, 1-15. https://doi.org/10.1016/j.jhazmat.2009.03.137

[26] Ghosh, U., Gillette, J.S., Luthy, R.G. and Zare, R.N. (2000) Microscale Location, Characterization, and Association of Polycyclic Aromatic Hydrocarbons on Harbor Sediment Particles. Environmental Science \& Technology, 34, 1729-1736. https://doi.org/10.1021/es991032t

[27] Wang, X.C., Zhang, Y.X. and Chen, R.F. (2001) Distribution and Partitioning of Polycyclic Aromatic Hydrocarbons (PAHs) in Different Size Fractions in Sediments 
from Boston Harbor, United States. Marine Pollution Bulletin, 42, 1139-1149. https://doi.org/10.1016/S0025-326X(01)00129-1

[28] Rockne, K.J., Shor, L.M., Young, L.Y., Taghon, G.L. and Kosson, D.S. (2002) Distributed Sequestration and Release of PAHs in Weathered Sediment: The Role of Sediment Structure and Organic Carbon Properties. Environmental Science \& Technology, 36, 2636-2644. https://doi.org/10.1021/es015652h

[29] Talley, J.W., Ghosh, U., Tucker, S.G., Furey, J.S. and Luthy, R.G. (2002) Particle-Scale Understanding of the Bioavailability of PAHs in Sediment. Environmental Science \& Technology, 36, 477-483. https://doi.org/10.1021/es010897f

[30] Ni, J.Z., Luo, Y.M., Wei, R. and Li, X.H. (2008) Distribution of Polycyclic Aromatic Hydrocarbons in Particle Size Separates and Density Fractions of Typical Agricultural Soils in the Yangtze River Delta, East China. European Journal of Soil Science, 59, 1020-1026. https://doi.org/10.1111/j.1365-2389.2008.01066.x

[31] Yang, Y., Ligouis, B., Pies, C., Grathwohl, P. and Thilo, H. (2008) Occurrence of Coal and Coal-Derived Particle-Bound Polycyclic Aromatic Hydrocarbons (PAHs) in a River Floodplain Soil. Environmental Pollution, 151, 121-129. https://doi.org/10.1016/j.envpol.2007.02.020

[32] Page, A.L. (1982) Methods of Soil Analysis. 2nd Edition, ASA Press, New York.

[33] Elliott, E.T. (1986) Aggregate Structure and Carbon, Nitrogen, and Phosphorus in Native and Cultivated Soils. Soil Science Society of America Journal, 50, 627-633. https://doi.org/10.2136/sssaj1986.03615995005000030017x

[34] Hatzinger, P.B. and Alexander, M. (1995) Effects of Aging of Chemicals in Soil on Their Biodegradability and Extractability. Environmental Science \& Technology, 29, 537-545. https://doi.org/10.1021/es00002a033

[35] Li, J.G., Sun, H.W. and Zhang, Y. (2007) Desorption of Pyrene from Freshly-Amended and Aged Soils and Its Relationship to Bioaccumulation in Earthworms. Soil and Sediment Contamination, 16, 79-87. https://doi.org/10.1080/15320380601079665

[36] Maliszewska-Kordybach, B. (2005) Dissipation of Polycyclic Aromatic Hydrocarbons in Freshly Contaminated Soils-The Effect of Soil Physicochemical Properties and Aging. Water, Air, and Soil Pollution, 168, 113-128.

https://doi.org/10.1007/s11270-005-0940-3

[37] Mechlińska, A., Gdaniec-Pietryka, M., Wolska, L. and Namieśnik, J. (2009) Evolution of Models for Sorption of PAHs and PCBs on Geosorbents. TrAC Trends in Analytical Chemistry, 28, 466-482. https://doi.org/10.1016/j.trac.2009.01.005

[38] Tam, N.F.Y., Ke, L., Wang, X.H. and Wong, Y.S. (2001) Contamination of Polycyclic Aromatic Hydrocarbons in Surface Sediments of Mangrove Swamps. Environmental Pollution, 114, 255-263. https://doi.org/10.1016/S0269-7491(00)00212-8

[39] Zhang, J., Cai, L.Z., Yuan, D.X. and Chen, M. (2004) Distribution and Sources of Polynuclear Aromatic Hydrocarbons in Mangrove Surficial Sediments of Deep Bay, China. Marine Pollution Bulletin, 49, 479-486.

https://doi.org/10.1016/j.marpolbul.2004.02.030

[40] Tisdall, J.M. and Oades, J.M. (1982) Organic Matter and Water-Stable Aggregates in Soils. Journal of Soil Science, 33, 141-163. https://doi.org/10.1111/j.1365-2389.1982.tb01755.x

[41] Flores-Cervantes, D.X., Plata, D.L., MacFarlane, J.K., Reddy, C.M. and Gschwend, P.M. (2009) Black Carbon in Marine Particulate Organic Carbon: Inputs and Cycling of Highly Recalcitrant Organic Carbon in the Gulf of Maine. Marine Chemistry, 113, 172-181. https://doi.org/10.1016/j.marchem.2009.01.012 
[42] Sánchen-García, L., Cato, I. and Gustafsson, Ö. (2010) Evaluation of the Influence of Black Carbon on the Distribution of PAHs in Sediments from along the Entire Swedish Continental Shelf. Marine Chemistry, 119, 44-51.

https://doi.org/10.1016/j.marchem.2009.12.005

[43] Xia, X.H., Li, Y.R., Zhou, Z. and Feng, C.L. (2010) Bioavailability of Adsorbed Phenanthrene by Black Carbon and Multi-Walled Carbon Nanotubes to Agrobacterium. Chemosphere, 78, 1329-1336.

https://doi.org/10.1016/j.chemosphere.2010.01.007 